\title{
Localization of Collaborative Planning and Teaching in Hong Kong
}

\author{
Man Yi Helen Chan \\ Teacher-Librarian \\ Senior Teacher \\ Lam Tin Methodist Primary School \\ Hong Kong (China)
}

\begin{abstract}
Collaborative Planning and Teaching (CPT) is vital under the impetus of technological innovation in the modern society. It advocates the integration of information skills into school curricula, provokes students' information literacy and facilitates student learning to learn. This article will look at various aspects of integrating information skills through CPT in Hong Kong primary schools from the marco level and the micro level. Problematic issues regarding cooperation among teacher-librarians, teachers and the use of resources in the school will be raised and discussed with suggested solutions. Based on the experiences in cooperation and the pros and cons of the status quo, this paper is concluded by presenting scenarios of CPT at the next stage.
\end{abstract}

\section{The importance of CPT in the Hong Kong context from the macro point of view}

The dynamic changing environment of the ever-advancing knowledge-based society makes obsolete traditional education systems, which stress passive learning, rote-memory, spoon-feeding of knowledge with teachers as sole distributors of knowledge. Education systems of different regions have become more focused on student-oriented learning, learning processes and self-taught skills under the new paradigm of learning to learn. Therefore, effective learning of information skills through CPT is highlighted in local context.

The key competency of learning to learn through information skills is a solid foundation for life-long learning in the Hong Kong education reform launched in 2000. As stated from the overall aim of the school curriculum, learning to learn is one of the essential qualities for wholeperson development of the 21st century. To support students, learning to learn becomes an overarching principle in school practices (CDC, 2002). One of the learning strategies of achieving the target is the application of information skills (CDI, 2002) through CPT. The idea of CPT between teacher and teacher-librarians are suggested in the official document of education reform (CDC, 2002; CDI, 2002). Upon the collaborative issue, the teachers focus on the subject content while the teacher-librarians concentrate on the teaching of information skills. The implementation of the local primary school curriculum can therefore draw the collaborative power of different professional calibre. Through integrating information skills into existing school curricula with subject teachers and teacher-librarians working as equal partners in CPT, 
students obtain essential information processing competencies such as to process information from a variety of print, non-print and electronic resources. The information skills application, therefore, empowers students with the capabilities of learning to learn (CDC, 2002). Many proactive Hong Kong teacher-librarians, who have based on their knowledge of the information skills models, initiate programs in local primary schools. Among the models, Eisenberg and Berkowitz's (2000) Big Six Model is the most popular one. Nevertheless, there is a lack of comparative study of foreign and local information skills programs.

\section{Undertaking comparative studies}

The complex interaction of global trend and local responses in education system cannot easily be understood without the use of comparative studies, as only through such studies could one consider the subject matter from both macro- and micro-level forces which shape education systems (Arnove and Torres, 1999). Comparative studies allow us to understand the strength and weakness in the local practice of CPT. Moreover, it provokes us to suggest possible solutions from the good practices of others. The education systems of the ESF and local primary schools will be analyzed from different facets here, which are the integration of information skills through CPT, teacher quality and school policies.

\section{Integration of information skills through CPT}

Integration of information skills in curriculum is noteworthy in both the ESF and local primary school curricula. In the case of the ESF, which follows the National Curriculum of England and Wales (Qualifications and Curriculum Authority, 2002), information skills are implicitly incorporated across different subjects. The national curriculum guidelines and standards mobilize the importance of learning the concepts, skills, and attitudes of information literacy in three main levels. Information skills such as setting targets, using a plan, problem solving, reading, obtaining, summarizing, synthesizing, organizing and presenting information are stressed across the curriculum of different key stages with close cooperation of teachers and school librarians throughout the process of CPT.

Similar to the ESF, the integration of information skills in curriculum can also be found in the documents of local primary school curriculum. Instead of being a matter for all class teachers, information skills teaching is mainly put on the burden of teacher-librarians in the local primary school curriculum. Examination of information skills in the local primary sector can be divided into two levels. At the first level, teacher-librarians' input in curriculum planning and teaching is highlighted in local primary education system. As stated in the Basic Education Curriculum Guide (CDC, 2002) Section 3.2.2 and 7.4.3, the specific role of teacher-librarians as information and media specialists in developing students' information skills and attitudes in using information from all available formats and contexts automatically highlights the important contribution of teacher-librarians in the local education system. The idea of CPT between teachers and teacher-librarians are suggested in the official document of educational reform (CDC, 2002; CDI, 2002). Upon the collaborative issue, the teachers focus on the subject content while the teacher-librarians concentrate on the teaching of information skills. The implementation of the local primary school curriculum can therefore draw the collaborative power of different professional calibre. 
2. Teacher quality: All-round ESF teachers versus professional local teacher-librarians

The framework of curriculum determines the professional requirements of teachers' and teacher librarians' qualification in different systems. The ESF system demands all-round teachers and the local primary education system requires professional teacher-librarians for the implementation of information skills in the school programs. In the ESF system, all teachers are required to have well-developed ICT skills in supplementing to their teaching qualifications (ESF, SCMP, January 11, 2003) in recruitment. The ESF class teachers are assumed to teach most lessons of a class, include Library lessons. Thus, CPT is naturally run with the requirement of the curriculum. For the local primary school system, different subject teachers are trained to teach specific subjects. Teacher-librarians, being the professional of school library, are mainly in charge of the library and its related programs, though principals may assign teacher-librarians in subject teaching or other school works in some cases.

3. Flexible learning policies vis-à-vis compartmentalized subject-based policies

The differences in information skills application through CPT in the ESF and the local primary schools are highly affected by the policies and measures of the two systems respectively. The examination of the learning mode is examined with focus on the flexible timetable here. The ESF adopt the flexible mode of learning. The ESF class teachers are in charge of most class lessons, which include Numeracy, Spelling, Reader's Workshop, Writer's Workshop and Library. It therefore facilitates the coherence and integration teaching and learning experiences of information skills through CPT across different subjects of each level.

Incorporation of information skills through CPT into the curriculum is the work of teaching staff rather than teacher librarians in the ESF. Teacher librarians concentrate their efforts on the service provision in the school libraries. Initiative of teaching staff in using library resources and ICT resources becomes the key concern in the information skills implementation. As noted by the ESF school librarians and observed in the school library visits of the four ESF schools, teachers were working harmony with the teacher librarians during the process of CPT.

In contrast with the flexible learning policies of the ESF system which facilitate teaching and learning of information skills through CPT, the comparatively rigid policies and measures of local primary school system prompt the alternative development of CPT implementation in individual local primary schools. The fragmentation of various subjects and activities offered in the schooling timeframe defers the development of CPT integrated curriculum. Different subjects and learning activities are found in the timetable with most of the lesson lasts for only thirty-five minutes. All subjects have their own subject contents with little connection between each other. Considerable transitional time between lessons also impedes the consistency of information skills learning with multiple tasks. 


\section{Challenges of CPT implementation}

Challenges of CPT application are faced by the local primary schools. Challenges are mainly from professional training of teaching staff, resources, facilities and time for CPT among staff. Most principals of local primary schools see the value of CPT application. However, they also perceive the constraint of CPT development in schools. The major concern for CPT implementation in the local primary school education is the professional training of teaching staff. Teacher-librarians cannot be the sole group of people to integrate information skills through CPT in a school-wide teaching and learning spectrum. At least a team of teaching staff, and preferably all teaching staff, must equally own the professional knowledge and skills of implementing information skills program in order to facilitate CPT and information skills implementation at each learning level.

Secondly, school libraries and computers are valuable resources and facilities for local primary school students' information skills learning. Limited resources and facilities as found in some schools largely confine the students' learning of information skills through CPT in the school learning environment.

Last but not least, one of the side effects of educational changes across different educational matters is intensive meeting of teachers in different domains. Unless these meetings are set within teaching time-table, teachers of local primary schools need to find time for these meetings after schools or in the resting time within the daily teaching schedule. Time for CPT in information skills implementation seems rather difficult under the tight teaching and meeting schedule of the local primary school teachers.

\section{Micro level: Favorable factors in CPT implementation}

The input forces from the school level, which are shaped under macro influences, directly affect the information skills learning process through CPT and students' information literate learning outcome. The constraints discussed above are faced by most local primary schools. The key driving forces of Lam Tin Methodist Primary School will be critically analysis below to foresee possible solutions of some problems in CPT implementation.

\section{Principal's support}

The support of the principal is absolutely important for the smooth running in the information skills implementation endeavor. The principal of Lam Tin Methodist Primary School confirmed the importance of staff collaboration in accelerating effective teaching and learning. The principals of local primary schools believed that CPT enables the flexible use of available resources within and outside schools for student's learning under collaboration among teaching staff and teacher-librarian.

The principal of Lam Tin Methodist Primary School believed that CPT propelled information skills learning, which were transferable to other subject learning and problemsolving in daily life. Therefore, information skills became a powerful tool in facilitating students 
learning to learn. The learning outcomes could be expanded when teachers are ready for the changes in pedagogy. The principal further suggested the introduction of such a program to all teaching staff by the teacher-librarian for professional development.

The principal' positive attitude towards CPT leads their diverse support in the implementation of information skills programs. The support of principal is key concern for the success of information skills program in the local primary schools under constraints of the education system. Some good practices of the school can be examined at two levels: namely, administration, and teaching and learning. At the administration level, the principal assigned the teacher-librarian as one of the key members in the aspect of school curriculum development. Thus, the teacher-librarian work closely with the panels of different subjects and Primary School Mistress Curriculum Development (PSM(CD)) in the development of school curriculum. The increasing understanding of the school curriculum at the side of teacher-librarians facilitates CPT operation and enhances the opportunity of information skills integration across curriculum. Moreover, the understanding of necessary needs from both parties also grants the teacherlibrarian and teachers the competence of applying different funding from outside resources such as the EMB (Education and Manpower Bureau) so as to further promote CPT across students' learning contexts.

At the teaching and learning level, some lessons have extended from 35 minutes to 45 minutes. Moreover, the principal supports the teacher-librarian to join different CPT or information skills related pilot studies with other teaching staff, encourages her to apply different funding in developing students' information literacy. These pilot studies and funding projects directly assist the collaboration of teaching staff and teacher-librarians in CPT and enhance the mutual understanding of respective professionals in quality curriculum implementation.

\section{Teacher's professional development}

Other than the teacher librarian's own professional development, the continuous professional development concerning CPT among staff of Lam Tin Methodist Primary School is key concern in the training calendar of the school each year. Professionals from EMB, universities such as the Hong Kong University, which provides professional courses for teacherlibrarians and different libraries, are invited to hold professional teacher training on Teacher Professional Development.

\section{Communication through existed meeting}

New development upon CPT, Reading to learn and school library are shared among staff regularly in staff meeting. Mutual understanding of various needs from different disciplines of the school is highlighted which support the development of CPT in the school. Informal meetings are treasured in CPT to reduce the burden of meetings among teaching staff. Favorable professional development programs of the school such as "Teacher Reading Program" and "Teachers' Reading Club" also enhance mutual understanding and support among staff, which at the same time, assist CPT in the school. 


\section{Future development of CPT}

As a result of school-based development in education reform, schools and teachers are empowered to lead prominent changes in CPT. Among various approaches of implementation, three major modes of CPT among the local primary schools are identified as feasible running approaches of CPT now and in the near future. They are the lassie faire mode, the fused mode and the segregated mode. The three modes of CPT approaches commonly treat teacherlibrarians as information skills providers and teachers as subject content specialists.

The lassie faire mode of CPT application offers no library lessons on the time-table. Implementation of information skills teaching and learning is largely based on the initiative approaching of the subject teachers to the teacher-librarian. Whenever the subject teachers need the help of teacher-librarian in resources or in information skills integration, they go to the teacher-librarian and plan their lessons together. The time-table of the teacher-librarian is open for the booking of different subject teachers. One may doubt the initiatives of the local primary school teachers. However, with encouragement and school policies set up by principals that each subject teacher had to collaborate with the teacher-librarian regularly, e.g. at least once in each semester at the first year of this lassie faire mode running, most teachers easily accept this running mode. Subject teachers and teacher-librarians cooperatively teaching in the same classroom or library became one of the teaching scenarios of the school. The experience of CPT between subject teachers and teacher-librarians will be kept in a portfolio each time. The accumulation of the portfolio permits repeatability of the lessons in the following school years. Time consumed on planning, searching information, designing teaching and learning tools will be saved in CPT. In addition, information skills are penetrated in the curriculum learning under the precise planning of the curriculum coordinator. For example, projects are planned for the learning of a single level in each school year. Thus, the burden of collaboration of the teacherlibrarian with different subject teachers in CPT is largely lessened. Assessment of the information skills application of students is mainly done by the teacher-librarian.

Fused mode is operated in some schools. It is called fused mode as an information skills continuum according to the learning needs of students is designed by teacher-librarians and teachers of different subjects. All the necessary information skills of each level are taught in the library lessons with teacher-librarians and class teachers conducting library lessons together. The design of the information skills continuum is based on two principles: the learning abilities of students at each level and the curriculum activities across different subjects of the year, for example, project work of General Studies. Appropriate information skills are arranged to meet the timing needs of different curriculum activities. Thus, the information skills are learnt in a meaningful context under a coherent learning pattern through teacher-librarians and subject teachers teaching the skills and context respectively most of the time. Assessment of students' information skills is mainly done by subject teachers. The learning result will be shared among teachers and teacher-librarians.

Segregated mode is found in some local primary schools. Information skills according to the Big Six Model are taught in library lessons solely by teacher-librarians. The teacherlibrarians can design the time and content of related lessons without the constraint of curriculum. Segregated information and library skills are taught in the library lessons most of the time. 
Instead of in-depth integration of information skills in curriculum with long term CPT relationship between teacher-librarians and subject teachers, sporadic CPT, which is based on the short term needs such as pilot studies of the Education and Manpower Bureau, borrowing resources or teacher-librarians' assistance in searching web site information is found.

\section{Conclusion}

The integrated information skills instruction through CPT has positive impact on students' mastery of subject knowledge. It also highly facilitates students' possession of information literacy competencies. The success of CPT, as indicated above, depends on the cooperation and support of principals, teachers and teacher-librarians. The needs of harmonious collaboration among all participants in CPT programs explain the importance of "human factors" in the development of CPT among schools of Hong Kong. And this paper has shown a feasible way of maximizing the strength of these human factors to the benefits of the students, who would become life-longer learners in the society.

\section{References}

Arnove, R. F. and Torres, C. A. (eds.) (1999): Comparative education: The dialectic of the global and the local. Lanham, Md.: Rowman \& Littlefield.

Curriculum Development Council (CDC) (2002): Basic education curriculum guide: Building on strengths (Primary1-Secondary 3). Hong Kong: Government Printer.

Curriculum Development Institute (CDI) (2002): The provision of services from school library to support teaching and learning. Hong Kong: Government Printer. [In Chinese].

Eisenberg, M. and Berkowitz, L. (2000): The Big 6 collection: The best of the Big 6 Newspaper. Worthington, Ohio: Linworth.

English Schools Foundation (ESF) (2003): “'Teaching vacancies for September 2003', South China Morning Post, January 11.

Qualifications and Curriculum Authority (2002): National Curriculum Online. Available <http:/ http://www.nc.uk.net/home.html>. Accessed January 22, 2003.

\section{Author Note:}

Man Yi Helen Chan, the Secretary of the Hong Kong Teacher-librarian Association, has participated in various presentation sessions and published articles at the school and local levels of the Hong Kong Special Administrative Region. After earning the B.Ed (First Class Honors) degree from the University of Hong Kong, she has served as a Teacher-librarian from Primary One to Primary Six in a Government Subsidized school and has taught in both library and General Studies disciplines. Her workload over the administration and management of the school is gradually increased after she gets M.Ed. (Distinction) degree from the University of Hong Kong. She is currently the Teacher-librarian and the Student Support Program Coordinator of the school. Her diversified interests in education and promotion of learning to learn in school context propel her to attain the Certification for Principalship in 2007. 